\title{
Cell viability study of thermo-responsive core-shell superparamagnetic nanoparticles for multimodal cancer therapy
}

\author{
Saqlain A. Shah • A. Majeed $\cdot$ M. A. Shafique • \\ K. Rashid $\cdot$ Saif-Ullah Awan
}

Received: 14 November 2012/ Accepted: 28 December 2012/Published online: 6 January 2013

(C) The Author(s) 2013. This article is published with open access at Springerlink.com

\begin{abstract}
This is a vital extension of our previously published work. Thermo-responsive copolymer coated superparamagnetic $\mathrm{MnFe}_{2} \mathrm{O}_{4}$ nanoparticles are tested for cell viability and affinity on HeLa carcinoma cells under different conditions. Nanoparticles were loaded with anticancer drug doxorubicin. Composite nanoparticles of average diameter $45 \mathrm{~nm}$ were of core-shell structure having magnetic core of about $18 \mathrm{~nm}$. Magnetic hyperthermia effects on cell viability and drug delivery were studied by exposing the cell suspension to high frequency magnetic field, and living cells were quantified using MTT method. There was almost absence of drug release at $37^{\circ} \mathrm{C}$. Drug was released at temperatures above lower critical solution temperature (LCST) by magnetic heating. LCST of the thermo-responsive copolymer was observed to be around $39{ }^{\circ} \mathrm{C}$. Below this temperature, copolymer was hydrophilic and swelled. But above LCST, copolymer could become
\end{abstract}

\section{S. A. Shah $(\bowtie)$}

Department of Physics, Forman Christian College (University), Lahore, Pakistan

e-mail: saqlain007pk@hotmail.com

\section{A. Majeed}

Department of Internal Medicine, Nazareth Hospital, Philadelphia, USA

M. A. Shafique

Center for Advanced Studies in Physics, GC University,

Lahore, Pakistan

K. Rashid

Pakistan Council of Scientific and Industrial Research, Lahore, Pakistan

S.-U. Awan

Department of Physics, Quaid-i-Azam University, Islamabad, Pakistan hydrophobic, expel water and drug and shrink in volume. Combination of hyperthermia and drug delivery effectively treated cancer cells.

Keywords Biomaterials - Magnetic materials · Nanostructures · Polymers

\section{Introduction}

There is a lot of research going on the biomedical applications of magnetic nanoparticles (MNP) like magnetic resonance imaging, cell separation, localized hyperthermia of cancer and controlled drug delivery. Appropriate biocompatibility of materials is very important, and in this regards iron oxide based magnetic nanoparticles are of key significance. Magnetic field gradient or any other efficient drug delivery system can be used for delivering particles to the tumor sites. When subjected to high frequency magnetic field, these nanoparticles generate heat due to Brownian, Néel and hysteresis losses (Shah et al. 2012). Around a temperature of $45^{\circ} \mathrm{C}$, the healthy body cells remain safe but the cancer cells become vulnerable to radiotherapy and chemotherapy and might even perish completely (Shah 2012; Shah et al. 2010a, b, 2011). This is the approximate temperature that results in mechanisms like protein denaturation, DNA cross linking and apoptosis; all are different cancer damaging mechanisms (Hildebrandt et al. 2002; Kumar and Mohammad 2011; Santos-Marques et al. 2006; Suto and Srivastava 1995). Tissue characteristics, magnetic heater parameters and particles concentration are those factors that influence the effectiveness of localized hyperthermia (Kumar and Mohammad 2011; Raaphorst et al. 1979; Shah et al. 2010a).

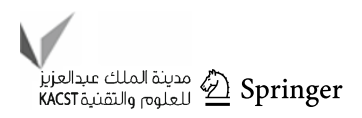


The most demanding aspect of MNP is the tailoring of multifunctional characteristics. Core-shell nanostructure is of the utmost importance in which MNP serve as magnetic cores. Opsonization and agglomeration are unwanted in such applications and could be prevented by functionalizing the surfaces of nanoparticles with functional polymers and/or surfactant layers that enhance the biocompatibility and act as shells over cores (Gupta and Gupta 2005; Luong et al. 2011; Martín-Saavedra et al. 2010). Anti-cancer drug can be attached to these particles to deliver to the cancer regions (Derfus et al. 2007; Kumar and Mohammad 2011). Localized hyperthermia and controlled drug delivery are two of the most pivotal purposes served simultaneously by the core-shell nanoparticles.

Another important set of compounds that have attracted huge attention in biomedical research are the functional substances that respond to external stimuli such as $\mathrm{pH}$ and temperature, etc. Thermo-responsive polymer PNIPAm (poly-n-isopropylacrylamide) is one of such functional compounds. It has an interesting characteristic of LCST (lower critical solution temperature). Below LCST, it absorbs water and swells in volume due to being hydrophilic. Above the temperature it expels water due to being hydrophobic and so shrinks in volume (Bromberg and Ron 1998; Hoffman 2002; Purushotham et al. 2009; SCHILD 1992; Schmaljohann 2006). By adjusting the temperature of the polymer shell, drug release can be manipulated resulting in higher release rates above LCST and vice versa (Coughlan et al. 2004; Liu et al. 2005; Purushotham et al. 2009; Zhang and Misra 2007). Co-monomer units such as acrylamide could be used to tune the LCST of PNIPAm (Sershen et al. 2000).

Present work is an in vitro study of multifunctional $\mathrm{MnFe}_{2} \mathrm{O}_{4}$ nanoparticles surface-modified with bilayer oleic acid and coated with a thermo-responsive copolymer PNIPAm-co-Am for controlled drug delivery and hyperthermia applications. Cell affinity and viability are studied

In Vitro Magnetic Hyperthermia

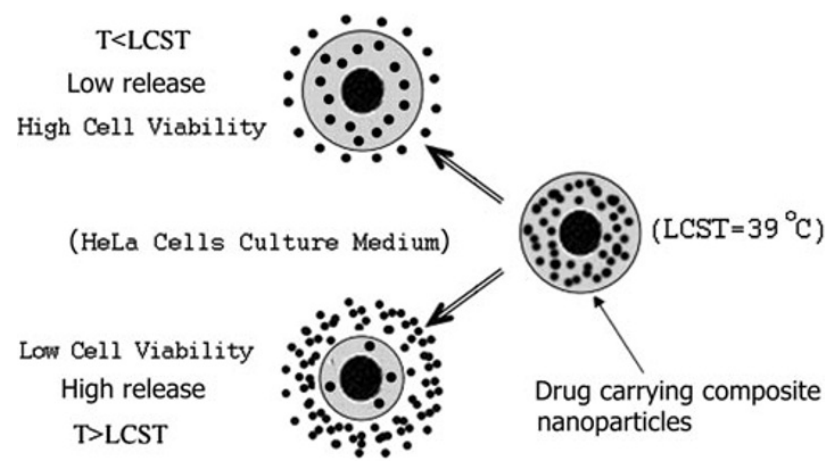

Fig. 1 Schematic overview of the processes involved in this study on HeLa carcinoma cells by MTT method. Figure 1 shows the schematic overview of the processes involved in this study.

\section{Experimental}

Current study is the vital extension of our previously published work (Shah et al. 2012). Bilayer oleic acidmodified $\mathrm{MnFe}_{2} \mathrm{O}_{4}$ magnetic nanoparticles (OA-MNP) were prepared by co-precipitation method and coated with PNIPAm-co-Am by emulsion polymerization. Anti-cancer drug doxorubicin (DOX) was loaded into the copolymer chains at $25{ }^{\circ} \mathrm{C}$. Detailed synthesis techniques of composite nanoparticles (CNP) are described in our previous work (Shah et al. 2012).

\section{In vitro study}

Magnetic hyperthermia and drug release

The in vitro study of composite magnetic nanoparticles was carried out on HeLa carcinoma cells. Cell viability/cytotoxicity of nanoparticles was determined using MTT method. MTT is a yellow, hydrophilic tetrazolium compound. When this dye is added to the metabolically active cells, it is converted into hydrophobic dark blue formazan due to cleavage reduction of tetrazolium (Kim et al. 2009). Formazan crystals are then dissolved in an organic compound dimethylsulfoxide (DMSO) forming a colored solution and then quantified by finding absorption at $570 \mathrm{~nm}$. The resultant value corresponds to the number of metabolically active cells. $30 \mathrm{mg}$ CNP were added to HeLa cells having concentration of $10^{5}$ cells $/ \mathrm{ml}$ and incubated for $24 \mathrm{~h}$ at an atmosphere of $5 \% \mathrm{CO}_{2}$ and $37{ }^{\circ} \mathrm{C}$, to allow the nanoparticles to bind to cells. After $24 \mathrm{~h}$, suspension was placed in a thermally insulating glass container and placed within the heating coil of a magnetic heater operating at $7.2 \mathrm{kA} / \mathrm{m}$ magnetic field and $70 \mathrm{kHz}$ frequency. Magnetic heater was operated such that $45{ }^{\circ} \mathrm{C}$ temperature was maintained for 2, 4 and $6 \mathrm{~h}$ for three types of observations. After hyperthermia treatments, suspension was placed in a 96-well plate and incubated for $12 \mathrm{~h}$. Subsequently $20 \mu \mathrm{l}$ of $5 \mathrm{mg} / \mathrm{ml}$ MTT was added to each well and incubated for $4 \mathrm{~h}$ at $5 \% \mathrm{CO}_{2}$ and $37^{\circ} \mathrm{C}$. Medium was removed after $4 \mathrm{~h}$ and crystals of formazan were mixed in $200 \mu \mathrm{l}$ of DMSO. The solution was vigorously mixed to dissolve the reactants. Microplate reader (AMP Platos $\mathrm{R}$-496) was used at $570 \mathrm{~nm}$ to determine the absorbance of each well. The relative cell viability percentage was determined by comparing with the control-wells without the magnetic nanoparticles. 
Cells affinity test

CNP (30 mg) were added to cell suspension of density $10^{5}$ cells $/ \mathrm{ml}$ and incubated for $24 \mathrm{~h}$ at $5 \% \mathrm{CO}_{2}$ and $37{ }^{\circ} \mathrm{C}$ to allow the nanoparticles to bind to cells. After $24 \mathrm{~h}$, magnetically bound cells were separated by magnetic decantation. Supernatant was processed with MTT assay to count the number of living cells after separating the magnetic cells. Cell affinity was determined by subtracting from the total number of cells.

\section{Results and discussions}

There are two reasons why the surface modification of MNP with OA was necessary as reported in last paper (Shah et al. 2012). First, it was to synchronize the attachment of the thermo-responsive copolymer to the MNP by acting as an adhesive providing affinity. Second, was to be used as a surfactant to curb the agglomeration existing because of hydrophobic nature of $\mathrm{MnFe}_{2} \mathrm{O}_{4}$ and the dipoledipole interactions. Size of nanoparticles is of key significance for biomedical applications. The most appropriate size range of composite nanoparticles is about $10-50 \mathrm{~nm}$ for drug delivery and hyperthermia applications (Purushotham et al. 2009). The average diameter of CNP in this work was about $45 \mathrm{~nm}$, of which $18 \mathrm{~nm}$ was the diameter of magnetic core. About $60 \%$ (wt) of the (hydrated) CNP was composed of water and organic compounds and the remaining consisted of $\mathrm{MnFe}_{2} \mathrm{O}_{4}$ core. Magnetic core was of pseudo single domain structure and exhibited superparamagnetism due to lack of coercive force (Shah et al. 2012). 'Lower critical solution temperature (LCST) of thermo-responsive copolymer was observed to be $39{ }^{\circ} \mathrm{C}$. Below this temperature, copolymer was hydrophilic and above this temperature, it became hydrophobic and expelled water and drug.

In vitro study on HeLa carcinoma cells

\section{Cells affinity}

Composite nanoparticles were added to the cell culture medium and incubated for $24 \mathrm{~h}$ to allow the nanoparticles to attach with the cells. Figure 2 shows the cell capture rates of MNP, OA-MNP and CNP determined by MTT method. About $79 \%$ of the cells captured nanoparticles suggesting the appropriate cell affinities of CNP. MNP showed only $20 \%$ affinity to the cells in $24 \mathrm{~h}$ indicating their passivity in attaching with the cells in uncoated form. OA-modified nanoparticles showed capture rate of about $47 \%$ cells. The rising of the cells affinity was due to the biocompatible layers coated onto the particles. The attachment with the cells probably occurred due to the $\mathrm{CH}_{3}{ }^{+}$functional groups of PNIPAm-co-Am copolymer that might have interacted electrostatically with the negatively charged glycocalyx on the surface of cancer cells. Cancer cells are observed to be having a high density of negative charge on their surfaces due to the sialic acid residues and glycosaminoglycans on the cell membranes (Kim et al. 2009).

\section{In vitro magnetic hyperthermia}

Magnetic hyperthermia characteristics of OA-MNP and CNP were studied by incubating nanoparticles with cells in culture medium for $24 \mathrm{~h}$ and then subjecting the suspension to alternating magnetic field of $7.2 \mathrm{kA} / \mathrm{m}$ and frequency $70 \mathrm{kHz}$ for $1 \mathrm{~h}$. Temperature profile with time of magnetic heating is shown in Fig. 3. For both observations initial temperature was $25^{\circ} \mathrm{C}$. For 60 min magnetic heating, CNP caused a temperature increase of about $47^{\circ} \mathrm{C}$ while the temperature of the suspension containing OAMNP increased to about $67^{\circ} \mathrm{C}$. It took $35 \mathrm{~min}$ for the temperature of the CNP to rise up to $45^{\circ} \mathrm{C}$, which is an appropriate and effective temperature for hyperthermia therapy. Various cellular damaging processes may occur at this temperature like DNA cross linking, apoptosis and protein denaturation (Hildebrandt et al. 2002; Kumar and Mohammad 2011; Santos-Marques et al. 2006; Shah 2012; Suto and Srivastava 1995). By adjusting more suitable magnetic parameters like frequency and strength and the concentration of magnetic particles, the magnetic heating can be further optimized. As described earlier, size of the magnetic core is about $18-20 \mathrm{~nm}$ that forms a pseudo single domain structure. Particles exhibit superparamagnetism due to the absence of remanence magnetization and coercive force and heating occurs due to Brownian and Néel losses. Swiftly changing direction of the magnetic moments along the applied field within the crystal lattice

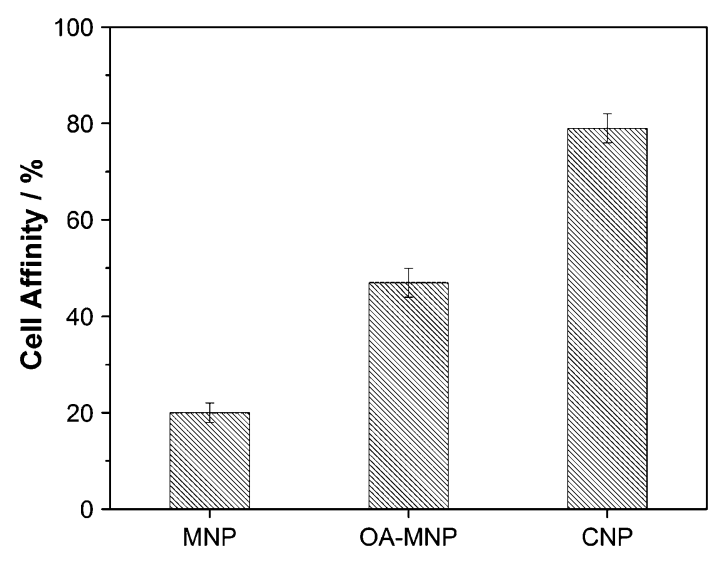

Fig. 2 Cell affinity of MNP, OA-MNP and CNP 
(internal dynamics) causes Néel relaxations. The torque of magnetic moments under the alternating field is hindered by the anisotropy energy (that attempts to align the moments along a particular axis within the crystal lattice). After the removal of applied field a reversible process of the relaxation of moments takes place toward their equilibrium position. Energy is dissipated in this process resulting in Néel heating. Under an alternating field, there also exists a physical rotation of the magnetic particles within the fluid medium which causes Brownian heating (external dynamics). Viscosity of the fluid is a determinant for Brownian relaxations. Lesser the viscosity of the medium, greater will be the Brownian heat loss and vice versa.

\section{Cell viability}

Cell viability/cytotoxicity of composite nanoparticles was studied using MTT assay on HeLa cells. Nanoparticles were incubated with cells in culture medium for $24 \mathrm{~h}$. Then suspensions were placed at 33,37 and $41{ }^{\circ} \mathrm{C}$ for $6 \mathrm{~h}$ for different observations and then incubated again for $12 \mathrm{~h}$ at $37^{\circ} \mathrm{C}$. Figure 4 shows the cell viability because of DOX release only in the absence of magnetic hyperthermia. Cell viability was almost maximum for temperatures below LCST where there was marginal DOX release due to diffusion process and copolymer was hydrophilic holding drug molecules in its chains. However, at $41{ }^{\circ} \mathrm{C}$ temperature exceeded LCST, copolymer became hydrophobic and expelled DOX that significantly reduced the cell viability to about $63 \%$ due to its anti-cancer effects. There was almost absence of drug release at $37{ }^{\circ} \mathrm{C}$ which is significant because CNP holds drug molecules during their transportation through the blood capillaries, and drug will be released to the surrounding only when temperature is made to increase above LCST by magnetic hyperthermia.

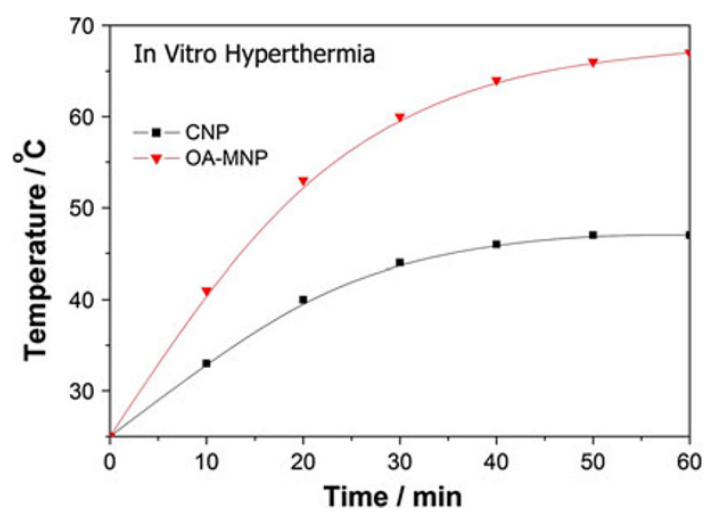

Fig. 3 In vitro heat generation of OA-MNP and CNP under alternating magnetic field

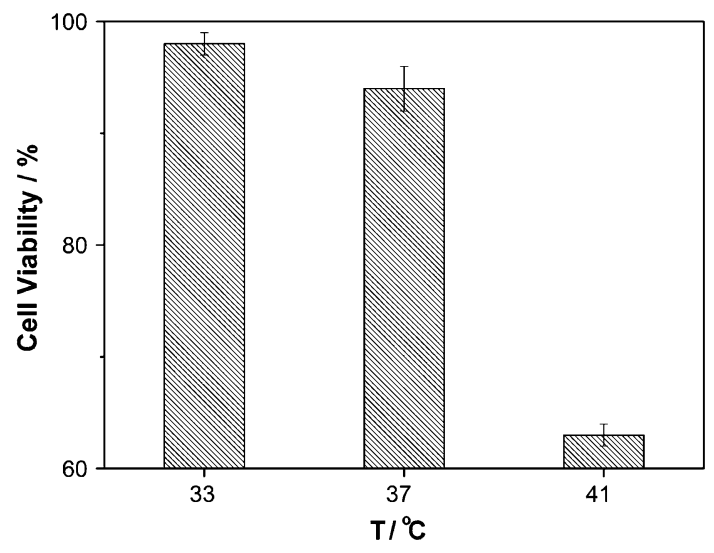

Fig. 4 Cell viability in the absence of magnetic heating (CNP (hydrated) were incubated with cells in culture medium for $24 \mathrm{~h}$. Then suspensions were placed at 33,37 and $41{ }^{\circ} \mathrm{C}$ for $6 \mathrm{~h}$ for different observations and then incubated again for $12 \mathrm{~h}$ at $37^{\circ} \mathrm{C}$.)

Dehydrated composite nanoparticles (without DOX) were incubated with cells for $24 \mathrm{~h}$ and then suspensions were subjected to alternating magnetic field of $7.2 \mathrm{kA} / \mathrm{m}$ and frequency $70 \mathrm{kHz}$ in such a way that temperature $45^{\circ} \mathrm{C}$ was maintained for 2,4 and $6 \mathrm{~h}$ for three different observations. After magnetic heating each suspension was incubated for $12 \mathrm{~h}$. Figure 5 shows that keeping cells at $45{ }^{\circ} \mathrm{C}$ for hours caused a remarkable decrease in the cell viability and it dropped to about $18 \%$ for $6 \mathrm{~h}$ magnetic heating. Same experiment of magnetic heating for 2, 4 and $6 \mathrm{~h}$ was repeated with DOX-loaded composite particles. Figure 6 shows that anti-cancer drug duly contributed to kill the cancer cells due to its release at temperatures above LCST and viability dropped to about $8 \%$ for $6 \mathrm{~h}$ magnetic heating.

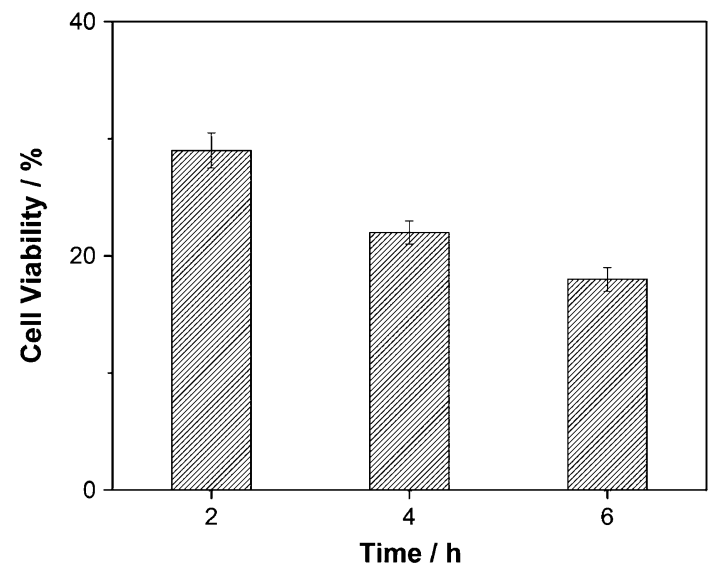

Fig. 5 Cell viability in the presence of magnetic hyperthermia only (dehydrated CNP (without DOX) were incubated with cells for $24 \mathrm{~h}$ and then suspensions were subjected to alternating magnetic field of $7.2 \mathrm{kA} / \mathrm{m}$ and frequency $70 \mathrm{kHz}$ in such a way that temperature $45^{\circ} \mathrm{C}$ was maintained for 2, 4 and $6 \mathrm{~h}$ for three different observations) 


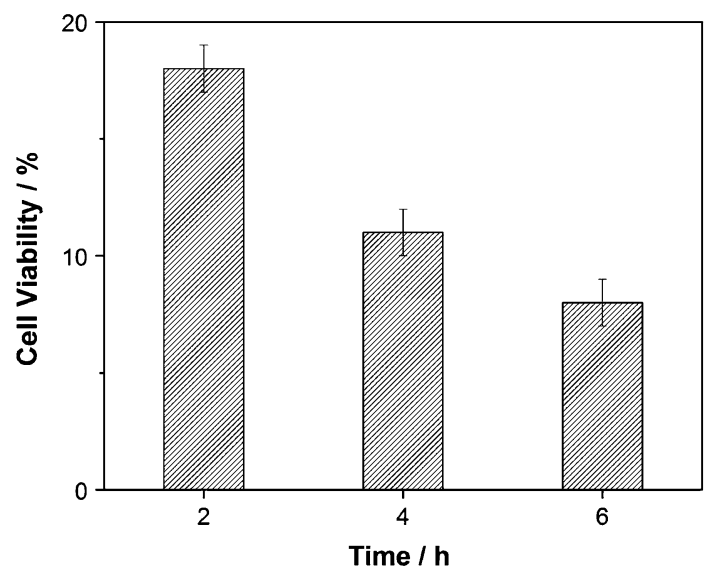

Fig. 6 Cell viability in the presence of magnetic hyperthermia and DOX (CNP (hydrated) were incubated with cells for $24 \mathrm{~h}$ and then suspensions were subjected to alternating magnetic field of $7.2 \mathrm{kA} / \mathrm{m}$ and frequency $70 \mathrm{kHz}$ in such a way that temperature $45^{\circ} \mathrm{C}$ was maintained for 2, 4 and $6 \mathrm{~h}$ for three different observations)

Moderate hyperthermia kills cancer cells by apoptosis or at least weakens the cells to enhance the effectiveness of additional procedures like radiotherapy and/or chemotherapy. Therefore, hyperthermia is mostly applied in combinations with other therapies and attaching anti-cancer drug with magnetic nanoparticles in this study is for the purpose of multifunctionality. Intensive hyperthermia may cause cell death due to necrosis in which cytotoxic effect of high temperature causes denaturation and coagulation of membrane and cytoplasmatic proteins (Hildebrandt et al. 2002). It is worth mentioning that in vivo conditions are more favorable than in vitro for hyperthermia because in vivo tumor cells are already under stress due to disorganized vascular system, low oxygen, higher acidic concentration, insufficient nutrients and unfavorable microenvironment. So tumor cells are less able to tolerate the additional stresses of hyperthermia than the healthy cells can do. It is expected that if composite nanoparticles in this work are examined in vivo, even better results may come out.

\section{Conclusion}

In vitro study was carried out on HeLa cells for cell affinity and viability under different conditions. Hyperthermia effects on cell viability were studied by exposing the cell suspensions to high frequency magnetic field. There was almost absence of drug release at $37{ }^{\circ} \mathrm{C}$. Drug was released at temperatures above LCST due to magnetic hyperthermia that damaged the cell viability due to the combination of hyperthermia and drug effects. Composite particles exhibited appropriate cell affinity.

Acknowledgments Acknowledging every kind of assistance of M.H. Asdi from Stuttgart University Germany.
Open Access This article is distributed under the terms of the Creative Commons Attribution License which permits any use, distribution, and reproduction in any medium, provided the original author(s) and the source are credited.

\section{References}

Bromberg LE, Ron ES (1998) Temperature-responsive gels and thermogelling polymer matrices for protein and peptide delivery. Adv Drug Deliv Rev 31:197-221

Coughlan DC, Quilty FP, Corrigan OI (2004) Effect of drug physicochemical properties on swelling/deswelling kinetics and pulsatile drug release from thermoresponsive poly(N-isopropylacrylamide) hydrogels. J Cont Release 98:97-114

Derfus AM, von Maltzahn G, Harris TJ, Duza T, Vecchio KS, Ruoslahti E, Bhatia SN (2007) Remotely triggered release from magnetic nanoparticles. Adv Mater 19:3932-3936

Gupta AK, Gupta M (2005) Synthesis and surface engineering of iron oxide nanoparticles for biomedical applications. Biomaterials 26:3995-4021

Hildebrandt B, Wust P, Ahlers O, Dieing A, Sreenivasa G, Kerner T, Felix R, Riess H (2002) The cellular and molecular basis of hyperthermia. Crit Rev Oncol Hematol 43:33-56

Hoffman AS (2002) Hydrogels for biomedical applications. Adv Drug Deliv Rev 54:3-12

Kim D-H, Kim K-N, Kim K-M, Lee Y-K (2009) Targeting to carcinoma cells with chitosan- and starch-coated magnetic nanoparticles for magnetic hyperthermia. J Biomed Mater Res A 88A:1-11

Kumar CSSR, Mohammad F (2011) Magnetic nanomaterials for hyperthermia-based therapy and controlled drug delivery. Adv Drug Deliv Rev 63:789-808

Liu SQ, Tong YW, Yang YY (2005) Incorporation and in vitro release of doxorubicin in thermally sensitive micelles made from poly(N-isopropylacrylamide-co-N, N-dimethylacrylamide)-bpoly(D, L-lactide-co-glycolide) with varying compositions. Biomaterials 26:5064-5074

Luong TT, Ha TP, Tran LD, Do MH, Mai TT, Pham NH, Phan HBT, Pham GHT, Hoang NMT, Nguyen QT, Nguyen PX (2011) Design of carboxylated $\mathrm{Fe} 3 \mathrm{O} 4 /$ poly(styrene-co-acrylic acid) ferrofluids with highly efficient magnetic heating effect. Coll Surf A 384:23-30

Martín-Saavedra FM, Ruíz-Hernández E, Boré A, Arcos D, ValletRegí M, Vilaboa N (2010) Magnetic mesoporous silica spheres for hyperthermia therapy. Acta Biomater 6:4522-4531

Purushotham S, Chang PE, Rumpel H, Kee IH et al (2009) Thermoresponsive core-shell magnetic nanoparticles for combined modalities of cancer therapy. Nanotechnology 20:305101

Raaphorst GP, Freeman ML, Dewey WC (1979) Radiosensitivity and recovery from radiation damage in cultured $\mathrm{CHO}$ cells exposed to hyperthermia at 42.5 or $45.5^{\circ} \mathrm{C}$. Radiat Res 79:390-402

Santos-Marques MJ, Carvalho F, Sousa C, Remião F, Vitorino R, Amado F, Ferreira R, Duarte JA, de Lourdes Bastos M (2006) Cytotoxicity and cell signalling induced by continuous mild hyperthermia in freshly isolated mouse hepatocytes. Toxicology 224:210-218

Schild HG (1992) Poly (N-isopropylacrylamide): experiment, theory and application, vol 17. Elsevier, Kidlington

Schmaljohann D (2006) Thermo- and pH-responsive polymers in drug delivery. Adv Drug Deliv Rev 58:1655-1670

Sershen SR, Westcott SL, Halas NJ, West JL (2000) Temperaturesensitive polymer-nanoshell composites for photothermally modulated drug delivery. J Biomed Mater Res 51:293-298

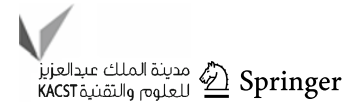


Shah SA (2012) Magnetic Hyperthermia for Cancer Treatment. Lambert Publishers, Lahore

Shah S, Hashmi MU, Shamim A, Alam S (2010a) Study of an anisotropic ferrimagnetic bioactive glass ceramic for cancer treatment. Appl Phys A 100:273-280

Shah SA, Hashmi MU, Alam S, Shamim A (2010b) Magnetic and bioactivity evaluation of ferrimagnetic $\mathrm{ZnFe}_{2} \mathrm{O}_{4}$ containing glass ceramics for the hyperthermia treatment of cancer. J Magn Magn Mater 322:375-381

Shah SA, Hashmi MU, Alam S (2011) Effect of aligning magnetic field on the magnetic and calorimetric properties of ferrimagnetic bioactive glass ceramics for the hyperthermia treatment of cancer. Mater Sci Eng C 31:1010-1016
Shah SA, Asdi MH, Hashmi MU, Umar MF, Awan S-U (2012) Thermo-responsive copolymer coated $\mathrm{MnFe}_{2} \mathrm{O}_{4}$ magnetic nanoparticles for hyperthermia therapy and controlled drug delivery. Mater Chem Phys 137:365-371

Suto R, Srivastava PK (1995) A mechanism for the specific immunogenicity of heat shock protein-chaperoned peptides. Science 269:1585-1588

Zhang J, Misra RDK (2007) Magnetic drug-targeting carrier encapsulated with thermosensitive smart polymer: core-shell nanoparticle carrier and drug release response. Acta Biomater 3:838-850 